\begin{tabular}{|lcc|}
\hline & $\begin{array}{c}\text { Osmanlı Medeniyeti Araştırmaları Dergisi } \\
\text { Journal of Ottoman Civilization Studies }\end{array}$ \\
e-ISSN 2458-9519 & $\begin{array}{c}\text { Cilt 6, Sayı 11, Ekim 2020 \& Vol 6, No 11, October } 2020 \\
\text { C2020 Telif Hakkı OSMED'e aittir }\end{array}$ \\
\hline DOI: $10.21021 /$ osmed.779789 & Makale Türü: Araştırma Makalesi & Article Types: Research Article \\
\hline Geliş Tarihi \& Received: 13.07 .2020 & Kabul Tarihi \& Accepted: 11.08 .2020 & OSMED, 2020, $6(11): 151-169$
\end{tabular}

\title{
Çanakkale Savaşlarının Amerikan Basınındaki Yansımaları
}

\author{
Reflections of Dardanelles Wars in the American Press
}

\section{Mehmet GÜNDÜZ*}

\section{Öz}

Gazeteler insanlara bilgi ulaştıran önemli kaynaklardandır. Bu kaynaklar tarihsel kanıt olma özelliğini ancak tarihçilerin onun karşısındaki tutumlarıyla edinirler. Tarihsel bir kaynak olarak gazeteler yayınladıkları dönemin anlaşılmasına yardımcı olurlar. Ayrıca bu kaynaklar okuyuculara bilginin nasıl sunulduğunun görülmesi ve dönemin algılarını göstermesi bakımından önemlidir. Hiç şüphesiz, yirminci yüzyılın ilk en önemli olayı Birinci Dünya Savaşı'dır. Bu savaşın da en önemli cephesi Çanakkale Cephesi'dir. Çanakkale'nin savaşın kaderine etki edecek kilit bir konumda olması dünya kamuoyunun dikkatini çekmesine sebep olmuştur. Bu yüzden savaş başladığı andan itibaren, Türk ve dünya basını bu konuyla yakından ilgilenmiş ve gelişmeleri kendi ülkelerine bildirmiştir. Amerikan basını da Çanakkale Cephesi'nde yaşanan gelişmeleri okuyucularına aktarmıştır. Birinci Dünya Savaşı'nın başlarında ABD'nin tarafsız bir ülke olması sebebiyle Amerikan basını her iki tarafta yaşanan gelişmeleri aktarmıştır. Çanakkale Savaşları'nda yaşanan gelişmelerin Amerikan basınında nasıl yer aldığı ve okuyuculara burada yaşanan olayların nasıl aktarıldığını incelemek bu çalışmanın asıl amacıdır. Bunun için Amerika'da yayımlanmış gazetelerin Çanakkale Savaşlarıyla ilgili yaptıkları haberler doküman analizi yöntemiyle incelenmiştir. Amerika basınında Çanakkale Savaşlarında Müttefik Devletlerin kazanmak için neredeyse her yola başvurdukları görülmektedir. Bu saldırılar karşında Türklerin ise büyük bir mücadele verdikleri görülmektedir.

Anahtar Kelimeler: Amerikan Basını, Çanakkale Savaşları, Gelibolu, Birinci Dünya Savaşı

\begin{abstract}
Newspapers are an important source of information to people. These sources acquire the feature of being historical evidence only with the attitude of historians towards it. As a historical resource, newspapers help to understand the period they publish. In addition, these sources are important in terms of seeing how the information is presented to the readers and showing the perceptions of the period. Undoubtedly, the first major event of the twentieth century is the First World War. The most important front in this war is the Çanakkale Front. The fact that Çanakkale was in a key position that will affect the fate of the war has caused the world public attention. Therefore, from the moment the war started, the Turkish and world press has been closely interested in this issue and reported the developments to their own countries. The American press also conveyed the developments on the Çanakkale Front to its readers. Since the USA was a neutral country at the beginning of the First World War, the American press reported the developments on both sides. The main purpose of this study is to examine how the developments in the Çanakkale Wars took place in the American press and how the events happened here were conveyed to the readers. For this, the news of the newspapers published in the USA about the Dardanelles Wars were examined through the document analysis method. In the American press, it is seen that the Allied States used almost every way to win in the Dardanelles Wars. In the face of these attacks, it is seen that Turks are fighting a great deal.
\end{abstract}

Keywords: American Press, Dardanelles Wars, Gallipoli, First World War

*(Dr.); İstanbul Erkek Lisesi, ekalim02@yahoo.com; ORCID:orcid.org/0000-0002-4642-4189

Kaynak Gösterme: Gündüz, M. "Çanakkale Savaşlarının Amerikan Basınındaki Yansımaları". Osmanlı Medeniyeti Araştırmaları Dergisi, 6 (2020): 151-169. 


\section{Giriş}

Çanakkale Boğazı Karadeniz, Marmara ve Ege Denizlerini birbirine bağlayan tarihi bir suyoludur. Tarih boyunca birçok devletin sahip olmak isteği bu yer Osmanlılar tarafindan Avrupa'da ilk fethedilen yer olan Çimpe Kalesi'ni barındırmaktadır. Çimpe Kalesi stratejik önemi sebebiyle Osmanlı Devleti'nin yüzyıllar boyunca Avrupa'daki ilerlemesinin önemli noktası olmuştur. Müttefiklerin Çanakkale Boğazı'na saldırmasıyla burası dünya gündemine yeniden gelmiştir.

Boğazlar hem Müttefikler hem de İttifak Devletleri için çok önemli geçiş noktalarıydı. Karadeniz'in bir Rus gölü olma olasılığının dünyayı büyük ölçüde ilgilendirdiği yazan Evening Star gazetesi Boğazlar üzerinde tarihi süreç içinde yaşanan gelişmelere değinmiş ve 1774 yılında Rusya'nın ticaret gemilerini Karadeniz'de dolaştırma hakkı elde ettiğini yazmıştır. XIX. yüzyılda harem kutsallığına sahip Karadeniz kavramının tamamen dağıldığını ileri sürmüş olan gazete Avrupa diplomasisi ile Akdeniz'deki güç dengesinin Boğazların savaş gemilerine kapatılması gerektirdiğini ve bu yüzden Boğazlardan geçecek savaş gemileri için padişahtan izin alınmasının hükme bağlandığını yorumunda bulunmuştur. Gazete ayrıca Rusya'nın, Prusya'nın Fransız İmparatorluğu'nu paramparça ettiği 1870 sonbaharında Karadeniz'i savaş gemilerine kapatarak tarafsız hale getiren 1856 Paris Antlaşması'nın hükümlerine uymadığını açıklamıştır. ${ }^{1}$ Rusya ile savaşı göze alamayan Âlî Paşa ise İngiliz siyasetine dayanmayı tercih etmiştir. İngiltere'nin davetiyle, Londra'da 17 Ocak 1871'de Osmanlı Devleti, Almanya, Avusturya, İngiltere, Fransa, İtalya ve Rusya'nın katılmalarıla bir konferans toplanmış ve 13 Mart 1871'de Londra Antlaşması imzalanmıştır. $\mathrm{Bu}$ antlaşmayla Karadeniz'in tarafsızlığı kaldırılmış ve Osmanlı Devleti'ne Boğazları barış zamanında kapalı tutmak mecburiyetini yükleyen madde de iptal edilmiştir. ${ }^{2}$ Evening Star gazetesi 1877 y1lında sadece Akdeniz'in değil tüm Avrupa ve Yakın Doğu'nun güç dengesinin Rusya'nın Türkiye üzerindeki zaferleri tarafından tehdit edilmesi üzerine İngiltere ve Almanya'nın Rusya'ya karşı harekete geçerek 13 Mart 1871'de Londra Antlaşması'nın yürürlükte kalmasını sağladığını yazmıştır. ${ }^{3}$

Çanakkale Savaşları dünya kamuoyunda önemli bir yer tuttuğundan çeşitli ülkelerin basını ve haber ajandaları burada yaşanan gelişmeleri okuyucularına duyurmak için bölgeye gazeteciler göndermiştir. Türkiye'ye gelmek için müracaat eden gazeteciler Almanya ve Avusturya-Macaristan Devletleri başta olmak üzere, savaşta tarafsız konumda olan İsveç, Danimarka, Hollanda, İspanya, Bulgaristan gibi Avrupa ülkeleri ile 1917'de savaşa taraf olarak dâhil olduğu tarihe kadar ABD vatandaşlarıydı. ${ }^{4}$ ABD vatandaşlarından Associated Press ve Paper Daily News muhabiri George Schreiner, Newyork Evening Mail muhabiri S.S. Clure, Associated Press muhabiri Theron Damon, Newyork Amerikan gazeteleri adına Granville Roland Fortescue, Amerika United Press adına G. Shepherd, Boston Post gazetesi adına Ferdinand Rainer gibi gazeteciler Çanakkale' deki gelişmeleri takip etmiştir. ${ }^{5}$ Gazetecilerin Çanakkale Savaşlarını Türk tarafında izleyebilmeleri için izin belgesi almaları gerekiyordu. George Schreiner izin belgesi alan gazetecilerden biriydi ve kendisine verilen izin belgesinde Schreiner'ın fotoğrafi, eşkâli, kaldığı yer, yaşı, bildiği diller, inancı ve kim tarafından referans verildiğine dair bilgiler yer almıştır. ${ }^{6}$

Çanakkale Savaşlarının ABD basınındaki yansımalarıyla ilgili Türkiye'de yapılan iki çalışmaya çalışma rastlanılmıştır. Bunlardan biri Tolga Başak'ın “The New York Times Gazetesinin Çanakkale Boğazı Günlüğü (1-31 Mart 1915)" adlı çalışması ile Mustafa Göleç'in "Amerikalı Bir Gazetecinin Gözüyle Çanakkale Deniz ve Kara Savaşlarl: George Abel Schreiner ve Çanakkale Günlükleri” adlı

${ }^{1}$ Evening Star, 24 Ocak 1915, s.5.

${ }^{2}$ Kemal Beydilli, "Boğazlar Meselesi”, DİA, İstanbul, 1992, C. VI, s.267.

${ }^{3}$ Evening Star, 24 Ocak 1915, s.5.

${ }^{4}$ Muzaffer Albayrak, "Çanakkale Cephesi'nde Yabancı Gazeteciler", 100. Yllında Çanakkale, (İstanbul: Zeytinburnu Belediyesi Kültür Yayınları, Mart 2016), s.196.

${ }^{5}$ Muzaffer Albayrak, a.g.m., s.197-198.

${ }^{6}$ BOA, DH. EUM. VRK, 25/9 
çalışmasıdır. ${ }^{7}$ Başak'ın çalışmasında 1-31 Mart 1915 tarihleri arasında The New York Times gazetesinde Çanakkale Boğazı Günlüğü başlı̆̆ıyla yayımlanmış haberlerin tercümesi yer almaktadır. Ancak Amerikan basınında Çanakkale Savaşlarıyla ilgili yapılan genel bir çalışmaya rastlanılmamıştır. Bu çalışma bütüncül bir bakış açısıyla Çanakkale Savaşlarının Amerikan basınında nasıl yer aldığını irdelemeyi amaçlamaktadır. Bu amaçla ABD'de yayımlanmış 42 gazetenin Çanakkale Savaşlarıyla ilgili haberleri incelenmiştir. Gazetelere başta Amerikan Kongre Kütüphanesi olmak üzere The New York Times gazetesi arşivinden ulaşılmıştır.

$\mathrm{Bu}$ çalışmada nitel araştırma yaklaşımı benimsenmiştir. Nitel araştırmalar, gözlem, görüşme ve doküman analizi gibi nitel veri toplama yöntemlerinin kullanıldığı, algıların ve olayların doğal ortamda gerçekçi ve bütüncül bir biçimde ortaya konmasına yönelik nitel bir sürecin izlendiği araştırmalardır. ${ }^{8}$ Araştırmada yöntem olarak ise doküman analizi yöntemi kullanılmıştır. Birçok araştırma yönteminin tamamlayıcısı olarak kullanılan doküman analizi, basılı veya elektronik belge/dokümanlardan anlam çıkarma, anlayış geliştirme ve araştırmaya dayalı bilgiye ulaşma amacıyla da tek başına sistematik bir izlek olarak kullanılabilir. ${ }^{9}$

\section{Amerika Basınında Gelibolu ve Çanakkale}

Amerika basınında Gelibolu ve Çanakkale ile ilgili tanıtıcı bilgiler yer almıştır. Gelibolu Yarımadası Çanakkale Boğazı'nın Avrupa kıyısını oluşturmaktadır. Burası kuzeyde derin girintili Saros Körfezi ile çevrilidir. Yarımada, 55 mil genişliğinde ve üç ila on üç mil arasında değişen engebeli bir araziye sahiptir. Marmara Denizi'ni bir Türk gölü olarak koruyan son nokta Gelibolu'dur. Güçlü bir müstahkem şehir olan Gelibolu'da, Rusların İstanbul'u ele geçirmekle tehdit ettiği 1878'den sonra modern tarzda savunma çalışmalarına başlanmıştır. Bu limanın güçlendirilmesi çalışmaları o zamandan beri Çanakkale Savaşlarına kadar düzensiz aralıklarla sürdürülmüştür. Bulgarlar Çatalca'daki hatlara saldırırken, Gelibolu Yarımadası ve Marmara Denizi yoluyla etraflarını çevirmek için çaba gösterebileceklerini hisseden Türkler, limanın savunmasına daha da önem vermiştir. ${ }^{10}$ "Çanakkale Asya 'yı açan altın anahtardır" diyen Wauwatosa News gazetesi Çanakkale şehrinin karşında yer alan Gelibolu'nun Edirne şehrinin antik limanı ve Ortaçağda önemli bir ticaret merkezi olduğunu yazmıştır. Gazete Çanakkale Boğazını koruyan Asya'da Çanakkale Avrupa'da ise dik bir çıkıntılı uçurumun kenarlarına inşa edilen Kilitbahir'in olduğunu okuyucularına aktarmıştır. ${ }^{11}$

The Caldwell Watchman bu bölgenin topraklarının son derece verimli ve tarıma uygun olduğunu okuyucularına aktarmıştır. Gazete 1915 yılında bölgede yaklaşık yüz bin kişi yaşamakta olduğunu, bölgede bazı değirmenler, balık işleme atölyesi, sınırlı deri ve ipek üretimi dışında önemli bir sanayi kuruluşunun olmadığını bildirmiştir. Yine 1915 'te yarımadanın ihracatının büyük bölümünü tahıl, peynir, et ürünleri ile deri ticareti oluşturmakta, yünlü ve pamuklu kumaş ile hırdavat ise ithal edilmekteydi ve Amerika Birleşik Devletleri'nin bu dönemde bu ticarette pratikte hiçbir rolü yoktu. ${ }^{12}$ Savaşta Gelibolu ve çevresinin neredeyse tamamının harap olduğu görülmekte, bu da bölgede yaşanan savaşın ne denli şiddetli geçtiğini göstermektedir.

7 Tolga Başak, "The New York Times” Gazetesinin Çanakkale Boğazı Günlüğü (1-31 Mart 1915)”, Atatürk Üniversitesi Edebiyat Fakültesi Sosyal Bilimler Dergisi, C.XI S.46, Haziran 2011, ss.1-42; Mustafa Göleç, "Amerikalı Bir Gazetecinin Gözüyle Çanakkale Deniz ve Kara Savaşları: George Abel Schreiner ve Çanakkale Günlükleri”, Çanakkale Araştırmaları Türk Yıllığı, Yıl: 13, Bahar 2015, S. 18, ss. 593-635.

${ }^{8}$ A. Yıldırım ve H. Şimşek, Sosyal Bilimlerde Nitel Araştırma Yöntemleri. (Ankara: Seçkin Yayınları, 2013), s.45

${ }^{9}$ G. A. Bowen, "Document Analysis As A Qualitative Research Method". Qualitative Research Journal, 2009 9(2), 27-40.

${ }^{10}$ The Appeal, 21 Ağustos 1915, s.1.

${ }^{11}$ Wauwatosa News, 2 Nisan 1915, s.6.

${ }^{12}$ The Caldwell Watchman, 7 Mayis 1915, s.8. 
New Britain Herald gazetesinde “Bombardımanla Harap Edilmiş Gelibolu” başlığıyla çıkan yazıda Müttefik saldırılarıyla Gelibolu'nun büyük oradan harap olduğu sadece birkaç evin sağlam kaldığı yazmıştır. Ayrıca tarlalarda hasadın yapılamadığı, köylerde kalan az sayıda dükkânın boş olduğu, limanlardaki teknelerin kaybolduğu, kasaba, köy ve kırsal kesimde yaşayanların bölgeyi terk ettiğini, sadece askerlerin bölgede kaldığı not etmiştir. Gazete İngiliz ve Fransız gemilerinin dar kara şeridine on binlerce ağır mermi attığını ve Gelibolu ile çevresindeki diğer yerleşim yerlerinin harabeye dönerek modern topçuların yapabileceklerinin bir parçası olarak durduğu belirtilmiştir. Gazete Müttefiklerin top ve uçak mühimmatı harcamalarının muazzam ve savurgan olduğunu da belirtmiştir. ${ }^{13}$ The Hattiesburg News gazetesi ise İngiliz gemilerinin topçu ateşine karşı yarımadadaki bir metrekarelik toprak parçasının güvenli olmadığını ancak sığınakların korunmaya yardımcı olduğunu yazmıştır. ${ }^{14}$

\section{Amerika Basınında Türk ve Müttefiklerin Askeri Güçleri}

ABD basını savaşta yaşanan gelişmelerin yanında tarafların askeri güç ve kabiliyetleri hakkında da çeşitli değerlendirmelerde bulunulmuştur. Bridgeton Pioneer gazetesi Çanakkale Boğazı'nın girişinde Asya yakasında Kumkale ve Avrupa yakasında ise Seddülbahir kalelerinin bulunduğunu ve bu kalelerin 15, 24 ve 28 santimetrelik kalibreli Krupp toplarıyla donatılmış ve tadil edilmiş eski iki kale olduklarını yazmıştır. Bu noktada Boğazın yaklaşık üç mil genişliğinde olduğunu yazan gazete Boğazın bu en dar noktasının etrafında Avrupa yakasında dokuz tahkimat olduğunu söylemiştir. Bunlardan en büyügünün 21 ve 35 santimetre kalibrelik yirmi bir Krupp topuna sahip olan Kilitbahir olduğunu belirten gazete Asya yakasında üç iyi silahlı kale olduğunu, bunların en büyügünün 35 santimetre kalibrelik on iki Krupp topuna sahip Çanakkale olduğunu yazmıştır. Müttefik gemilerinin bu noktada büyük direnişlerle karşılaştığını yazan gazete Boğazın yüksek noktalarında güçlü bir konuma sahip kalelerin büyük bir deniz kuvvetini tutabileceği yorumunda bulunmuştur. Gazete ayrıca Avrupa yakasında Alman askeri yetkililerinin gözetimi altında inşa edilmiş ve en yeni silahlarla donatılmış olan tahkimattan söz etmiş̧tir. ${ }^{15}$ Türklerin savunmada Alman silahlarından yararlandıkları görülmektedir.

Türk kuvvetlerine karşı1ık Müttefiklerin daha güçlü silahları olduğu Amerikan basınına yansımıştır. Müttefikler kruvazör, gemi, uçak ve toplarla Türklere saldırmıştır. Müttefikler uçakları savaş gemilerinin ateşini yönlendirmek için kullanılmıştı. ${ }^{16}$ İngilizlerin Ocean, Irresistible, Goliah, Triumph, Majestic, Agamemnon ve Kraliçe Elizabeth gibi, Fransızların ise Bouvet gibi savaş gemileri Müttefik donanmasında yer almıştır. ${ }^{17}$ The Pensacola Journal gazetesi Müttefik gemilerinin yarımadaya yönelik topçu ateşi olmasaydı tek bir İngiliz veya Fransız askerinin karaya ayak basamayacağını iddia etmiş ve günler boyunca Müttefik gemilerinin yarımadanın güney ucundaki her noktayı bombaladığını aktarmıştır. Böylece Osmanlı birlikleri neredeyse kıpırdayamaz hale getirilmiştir. Ancak gün geçtikçe Türkler daha fazla siper kazmışlar ve Müttefiklere karşı güçlü bir savunma hattı oluşturmuşlardır. ${ }^{18}$

Türklerin Müttefik saldırılarına karşı en önemli kozları ise tabyalar, toplar ve mayınlardı. The Ekalaka Eagle gazetesi geçmişte Çanakkale Boğazı'nı kontrol altına almak için verilen mücadelelere değindikten sonra Müttefik filosunun Çanakkale'ye girişinden sonraki üç hafta içinde, tarihte bilinen en ağır bombardıman sonucu Seddülbahir ve Kumkale'nin dış kalelerinin harabeye döndüğünü yazmıştır. Hamidiye Tabyasının gücüne değinen deniz uzmanları Boğazın ancak Hamidiye ve Kilitbahir yok edildikten sonra zorlanabileceğini söylemiştir. Çanakkale Boğazı'nın en dar olduğu yerlerde, modern

${ }^{13}$ New Britain Herald, 30 Ağustos 1915, s.5.

${ }^{14}$ The Hattiesburg News, 13 Ağustos 1915, s.4; Konuyla ilgili ayrıca bakınız: Hasan Mert, "Çanakkale'de Ölüm”, Tarih Incelemeleri Dergisi, C. XXVI, S. 1, Temmuz 2011, ss.151-172.

${ }^{15}$ Bridgeton Pioneer, 29 Nisan 1915, s.3.

${ }^{16}$ The Chickasha Daily Express, 6 Mayıs 1915, s.1.

${ }^{17}$ Bryan Daily Eagle and Pilot, 21 Mayıs 1915, s.1; The Ekalaka Eagle, 27 Ağustos 1915, s.6.

${ }^{18}$ The Pensacola Journal, 2 Ağustos 1915, s.1. 
silahlar ve savunma hatlarıyla donatılmış kalelerin bulunduğunu yazan gazete Çanakkale Boğazı'nın her iki yakasında kilometrelerce uzanan kıyıların Türk askerinin kontrolünde oluğunu ve burayı geçmenin çok kolay olmadığını okuyucularına aktarmıştır. ${ }^{19}$

Müttefik saldırıları karşında Türk askerlerine eski Alman kruvazörü Goben yani Sultan Selim Marmara Denizi'nden Türklere yardım etmiştir. Ayrıca Alman denizaltıları da savaşta etkin rol oynamıştır. Nitekim İngilizlerin Alman denizaltılarının imhasına yol açan herhangi bir bilgi için 10.000 dolar ödül verdiği Amerikan basınında yer almıştır. ${ }^{20}$ Çanakkale Boğazı'ndaki bataryalarda bulunan silahlarla ilgili tahminlerde bulunan Bridgeton Pioneer gazetesi buralarda bulunan silahların çoğunun eski teknolojiye sahip ve modern zırhlı gemilere karşı neredeyse işe yaramaz durumda olduğunu iddia etmiştir. ${ }^{21}$ Ancak savaşta Türklerin elindeki silah gücü Müttefiklerinki kadar güçlü olmasa da Türkler Müttefiklere karşı büyük başarılar kazanmıştır. Müttefiklere ait birçok savaş gemisi batırılmıştır. İngilizler 18 Mart 1915'te Ocean ve Irresistible, Nisan ayında Goliah, Mayıs ayında Triumph ve Majestic ile Agamemnon'u, Fransızların ise Bouvet adlı savaş gemilerini kaybetmiştir. ${ }^{22}$ Amerika basını bu büyük kayba sayfalarında geniş yer ayırmıştır. Grand Forks Daily Herald gazetesi Çanakkale Boğazı'ndaki Türk torpidolarının son kurbanının 1895 yılında inşa edilen ve 767 mürettebatı taşıyan, 27 Mayıs 1915 tarihinde batırılan Majestic gemisi olduğunu yazmıştır. ${ }^{23}$ Majestic, Çanakkale Boğazı'nda Türklere karşı düzenlenen operasyonlarda kaybedilen beşinci İngiliz zırhlısıydı. Aktif hizmetteki savaş gemilerinin en eskilerinden biri olmasına rağmen özellikle dört 12 inç ve on iki 6 inç toplarıyla bombardımanda etkili olmuştur. Türklerin siperleri ve savunmalarına zarar veren büyük kalibreli mermileri nedeniyle Müttefikler için önemli bir gemiydi. ${ }^{24} \mathrm{Bu}$ geminin batırılması Türkler için büyük bir zafer anlamına geliyordu. Nitekim Müttefik donanmasının verdiği kayıp XVII. ortalarında İngilizlerin Hollandalılarla yaptığı mücadelede ve 1905 yılında Japonya deniz savaşında yaşanan Rus kayıplarından daha büyüktü. Çeşitli zamanlarda bazı küçük gemilerin kaybına ek olarak İngiliz zırhlı gemilerinin devre dışı bırakılması İngiliz halkına büyük bir şok yaşatmıştır.

\section{Amerikan Basınında Çanakkale Savaşları}

Çanakkale'nin kilit bir konumda olması ve özellikle Rus buğdayının uluslararası pazarlara ulaşması ABD ticareti açısından önem taşımaktaydı. Bu yüzden ABD basını Çanakkale'de yaşanan gelişmelerle yakından ilgilenmiştir. Amerika Birleşik Devletleri 1917 yılına kadar Birinci Dünya Savaşı'na katılmayarak tarafsız kalmışıtır. Bu yüzden Osmanlı Devleti'nin Müttefik Devletlerle iletişiminde kimi zaman aracı rol oynamıştır. ${ }^{25}$

ABD tarafsı bir ülke olsa da kimi zaman Müttefikleri destekleyici hamleler yapmaktan geri durmamıştır. Resmi düzeyde ABD bu savaşla ilgili gelişmeleri İstanbul'daki Büyük Elçisi Henry Morgenthau vasıtasıyla yakından izlemiştir. Özellikle Rus buğdayının uluslararası pazarlara ulaşıp ulaşmaması ile ABD'yi ilgilendirdiğinden Boğazların kapatılması ABD'yi tedirgin etmiş, Morgenthau bu durumu kabul edilemez olarak nitelemiştir. Morgenthau ülkesi tarafsız olsa da kendisi gizli bir Müttefik hayranıydı ve ona göre İstanbul'un ele geçirilmesi birkaç günlük işti. ${ }^{26}$ İlerleyen günlerde elçinin tavrını daha net görmek mümkün olmuştur. Nitekim Büyükelçisi Müttefiklerin yaptığ1 uluslararası hukuka aykırı davranışları görmezden gelmiştir. İngilizlerin savaşta uluslararası hukuk kurallarına aykırı olarak savaş bölgesi dışında bulunan Gelibolu şehrini ve Hilâl-i Ahmer bayrağı taşıyan

${ }^{19}$ The Ekalaka Eagle, 27 Ağustos 1915, s.6.

${ }^{20}$ Bryan Daily Eagle and Pilot, 21 May1s 1915, s.1.

${ }^{21}$ Bridgeton Pioneer, 29 Nisan 1915, s.3.

${ }^{22}$ The Ekalaka Eagle, 27 Ağustos 1915, s.6.

${ }^{23}$ Grand Forks Daily Herald, 31 May1s 1915, s.1.

${ }^{24}$ Perth Amboy Evening News, 28 May1s 1915, s.1.

${ }^{25}$ BOA, HR. SYS, 2409/21; BOA, HR. SYS, 2409/53; BOA, HR. SYS, 2098/12

${ }^{26}$ Tolga Başak, a.g.m., s.2-3. 
hastane gemileri ile sağlık birliklerine ateş açıp Ezine, Havuzlar ve Halilpaşa Çiftliği’ndeki hastaneleri bombalamaları, ölülerin defnedilmesiyle ilgili işlemleri görüşmek üzere gönderilen Osmanlı delegesini alıkoymaları, hastane gemilerini askerî amaçla kullanmalarını, Mudanya ve Tekfurdağı'ndaki yolcu gemilerine denizaltıları aracılığıyla saldırmalarını görmezden gelen Morgenthau, Osmanlı Devleti'nin bu hukuksuzluklara cevap olarak İstanbul'daki İngiliz ve Fransız vatandaşlarını Gelibolu'ya yerleştirme yolunda aldığı kararı uluslararası hukuka aykırı olduğunu gerekçesiyle eleştirmiştir. ${ }^{27}$

\subsection{Deniz Savaşları}

Boğazların kontrolü için hem Müttefikler hem de İttifak Devletleri Birinci Dünya Savaşı öncesinde çeşitli girişimlerde bulunmuştur. Nitekim İngilizler Çanakkale Boğazı'nın donanmayla geçilmesi hakkında 1906, 1907 ve 1911'de böyle bir hareketin risklerini ve başarı şansını tartışan ayrıntılı raporlar hazırlamıştır. ${ }^{28}$ Savaş başlamadan önce İngiliz Savaş Bakanı Lord Kitchener ve Deniz Kuvvetleri Bakanı W. Churchill arasında Boğazlar konusunda geniş fikir alışverişi gerçekleşmiştir. ${ }^{29}$ İngilizlerin bölge üzerine dikkatini çeken bir diğer etken Yunan Başbakanı Venizelos'tu. Venizelos, bir çıkarma yapıldığı takdirde kara ve deniz kuvvetlerini tahsis edebileceğini İngiltere'ye bildirmiştir. ${ }^{30}$

1915'te ise İngiltere'nin Rusya'nın müttefiki olması Boğazlar konusunda Rusya'nın lehine bir durum oluşturmuştur. Rusya'nın Boğazlara hâkim olma düşüncesine olumlu yaklaşmakla birlikte İngiltere Rusya'nın Boğazları ele geçirince Almanya ile anlaşıp savaştan çekilmesinden korktuğu için çözümün kesin şeklini Almanya'nın yenilgisinden sonraya bırakmak istemiştir. ${ }^{31}$ Evening Star gazetesi Birleşik Devletlerin, Çanakkale Boğazı ve Karadeniz ile ilgili tüm sorulara akademik bir ilgi göstermekten başka bir şeye sahip değil yorumunda bulunmuştur. ${ }^{32} \mathrm{Bu}$ ortamda Birinci Dünya Savaş1 başlamış ve Osmanlı Devleti savaşa İttifak Devletlerinin yanında katılmak ve farklı birçok cephede savaşmak zorunda kalmıştır. Bu cephelerde Çanakkale Cephesi savaşın tüm tarafları için belki de en önemli cephe idi. Müttefik Devletler Osmanlı Devleti'nin başkenti İstanbul'u işgal ederek Osmanlı Devleti'ni saf dışı etmek istemiştir. Böylelikle hem Balkan devletlerinin Almanya'nın yanında savaşa girmesine engel olmayı hem de Rusya'ya gerekli yardımı ulaştırmayı amaçlamışlardır. Müttefikler Orta Avrupa'ya sızan Alman-Avusturya ordularını arkadan çevirmek için bu harekâtı gerekli görmüşlerdi. ${ }^{33}$ İngilizlerin bir diğer bir amacı da Osmanlı Devleti'ni barışa zorlayarak Türk ordusunun Mısır'ı tehdit etmesini önlemek ve Araplar ile İtalyanları kendi saflarına çekmek istemiştir. ${ }^{34}$ Nitekim bu şartlar altında Çanakkale Savaşları başlamıştır.

28 Eylül 1914'te Yunan zırhlılarının da bulunduğu yirmi dört gemiden oluşan İngiliz ve Fransız zırhlılarına Almanya'dan gelen gemilere ateş etme emri verilmiştir. Bu gemiler Boğazın girişini bombalamıştır. ${ }^{35}$ İlk deniz hücumu iki İngiliz harp gemisinin Ertuğrul ve Seddülbahir, iki Fransız gemisinin Kumkale ve Orhaniye tabyalarını 3 Kasım 1914'te bombalamasıyla başlamıştır. ${ }^{36}$ İtilaf Devletleri bu saldırıdan iki gün sonra Osmanlı Devleti'ne resmen savaş ilan etmiştir. Osmanlı Devleti bu olaya sekiz gün sonra cevap vermiştir. İngiltere ve Fransa kendileri Çanakkale'yi zorlarken

${ }^{27}$ BOA, HR. SYS, 2412/11.

${ }^{28}$ Mete Tuncoku, Çanakkale 1915 Buzdağının Altı, (Ankara: Türk Tarih Kurumu Basımevi, 2002), s.106.

${ }_{29}$ Mustafa Selçuk, "Çanakkale Savaşları Sırasında Osmanlı Hükümeti'ni ve Padişahı İstanbul'dan Taşıma Planları", Atatürk Araştırma Merkezi Dergisi, C. XXIV, S.70, s. 195-212.

${ }^{30}$ Ahmet Eyicil, "Çanakkale Savaşları," Gaziantep Üniversitesi Sosyal Bilimler Dergisi, 2009 8(1), s.318

${ }^{31}$ Kemal Beydilli, a.g.m., s.37

${ }^{32}$ Evening Star, 24 Ocak 1915, s.5.

${ }^{33}$ Zekeriya Kurşun, Çanakkale Muharebeleri, DİA, İstanbul, 1993, C. VIII, s.206

${ }^{34}$ BOA, DH. EUM. VRK, 25/8; Birinci Dünya Harbi'nde Türk Harbi, (Ankara: Genel Kurmay Basımevi, 1991), s.21.

${ }^{35}$ Osmanlı Belgelerinde Çanakkale Muharebeleri, (Ankara: Osmanlı Arşivi Daire Başkanlığı, 2005), C. I, 7-9.

${ }^{36}$ Zekeriya Kurşun, a.g.m., s.206 
Rusya'nın da İstanbul Boğazı'na girmesini teklif etmiş ancak Rusya donanmasının yetersizliğini ileri sürerek buna katılmamıştır. Rusya, İngiltere ve Fransa'nın Boğazları ele geçirmesini kendisi için tehlikeli bulduğundan 4 Mart 1915'te İstanbul ile Boğazlar ve çevresinin kendisine verilmesini talep etmiştir. İngiltere ve Fransa Rusya'nın bu isteklerini kabul etmiş ve böylece Rusya Boğazlar üzerindeki tarihî emellerini kâğıt üzerinde de olsa Fransa ve İngiltere'ye kabul ettirmiştir. ${ }^{37}$

Boğazlar hem Müttefikler hem de İttifak Devletleri için çok önemli geçiş noktalarıydı. Daha savaşın başlarında Amerikan basınında Boğazlar ve Karadeniz Meselesi üzerinde durulmuştur. İtilafların ikinci saldırısı ilk saldırıdan yaklaşık üç buçuk ay sonra 19 Şubat 1915'te gerçekleşmiştir. Şubat 1915'nin sonlarına doğru kırk Müttefik savaş gemisi Çanakkale Boğazı'na girmiş ve İntepe Hisarı'na saldırmıştır. ${ }^{38}$ Döneminin en büyük kalibreli ve güçlü silahlarına sahip en güçlü gemilerin bir kısmından oluşan Müttefik filosu birkaç Türk siperini ve Çanakkale'yi bombalamıştır. Ertuğrul ve Orhaniye tabyalarının tahrip edildiği bu saldırıdan sonra 26-27 Şubat 1915'te İtilaf Devletleri bu kez merkez tabyalarına saldırmışsa da bir sonuç alamamıştır. ${ }^{39}$

The Seward Gateway gazetesi saldırılar karşısında "Türk silahları geride kalmış gibi görünüyor ve iç kaleler korkunç saldırılara pek dayanamıyor" yorumunda bulunmuştur. Gazete ayrıca Çanakkale Boğazı'nın zorlanması durumunda İngilizlerin Saroz Körfezi'ne asker çıkarmalarının ve Ruslarla İstanbul'a eş zamanlı bir saldırı başlatarak Osmanlı Devleti'nin Avrupa topraklarının almalarının beklendiğini yazmıştır. İstanbul'un Müttefik filolar tarafından gerçek bir tehlike altında olduğunu belirten gazete Padişah ve ailesinin İstanbul'dan kaçmaya hazırlandığını iddia etmiştir. ${ }^{40}$ Dokuz Müttefik zırhlısının Çanakkale Boğazı'nın en dar kısmına ilerleyerek Türk tahkimatı ve birliklerini bombaladığını bildire Tonopah Daily Bozanza gazetesi Türkiye'nin durumun kritik hale geldiğini fark ettiğini ve birliklerini Çanakkale Boğazı'na sevk ettiğini yazmıştır. ${ }^{41}$ Evening Times-Republican gazetesi ise Gelibolu Yarımadası ve çevresini gösteren bir harita üzerinden bölge hakkında okuyucularına bilgiler sunmuştur. ${ }^{42}$

Bir ay içinde Marmara'ya girmeyi planlayan Müttefikler başarısız taarruzlardan sonra savaş kumandanlığında değişikliğine gitmek zorunda kalmıştır. Başkumandanlığa İngiliz Amirali Carden yerine en kıdemli Fransız kumandanı Amiral J. M. De Robeck tayin edilmiştir. Robeck de Carden gibi bütün gücüyle Çanakkale Boğazı'nı zorlayarak İstanbul'a ulaşmak için hazırlıklar yapmıştır. Ayrıca Türklerin savunmaları sonucunda Müttefikler savaş planlarını gözden geçirmek zorunda kalmış ve 17 Mart 1915'te Bozcaada'da Akdeniz Orduları Başkumandanı General Hamilton başkanlığında bir toplantı yapılmıştır. Deniz harekâtını bir hafta önce mayınlardan temizlenmiş olan Boğazın aşağı kesimlerinde bütün savaş gemileri kullanılarak Boğazın zorlanması olarak planlanmıştır. Fakat aynı günün gecesi Nusret mayın gemisinin Karanlık Liman bölgesini mayınlaması deniz harekâtının kaderini değiştirmiştir. ${ }^{43}$

18 Mart 1915 ’te Müttefik donanması büyük bir kuvvetle Türklere saldırdığ 1 ve saldırıda Fransız zırhlısı Bouvet ile İngiliz Ocean ve Irresistible savaş gemilerinin Türkler tarafından batırıldığı Amerikan basınında yer almıştır. ${ }^{44}$ Çanakkale'de yaşanan savaşla ilgili değerlendirmede bulunan The Ekalaka Eagle gazetesi Şubat 1915 'te İngiliz ve Fransız savaş gemilerinin bölgede yıkım yapmaya başladıklarını

${ }^{37}$ Kemal Beydilli, a.g.m., s.268.

${ }^{38}$ Bryan Daily Eagle and Pilot, 27 Şubat 1915, s.1.

${ }^{39}$ Zekeriya Kurşun, a.g.m., s.206

${ }^{40}$ The Seward Gateway, 27 Şubat 1915, s.1.

${ }^{41}$ Tonopah Daily Bozanza, 3 Mart 1915, s.1.

${ }^{42}$ Evening Times-Republican, 9 Mart 1915, s.5.

${ }^{43}$ Zekeriya Kurşun, a.g.m., s.206; Recep Şükrü Apuhan, Çanakkale Geçilmez, Dördüncü Baskı, (İstanbul: 2005), s.31-32.

${ }^{44}$ Bryan Daily Eagle and Pilot, 20 Mart 1915, s.1. 
ve Müttefiklerin 18 Mart 1915’te yaşadıklarını büyük kaybın özellikle İngiliz halkına büyük bir şok yaşattığını yazmıştır. Gazete geçmişte Çanakkale Boğazı'nı kontrol altına almak için verilen mücadelelere değindikten sonra Müttefik filosunun Çanakkale'ye girişinden sonraki üç hafta içinde, tarihte bilinen en ağır bombardıman sonucu Seddülbahir ve Kumkale'nin dış kalelerinin harabeye döndüğünü belirtmiştir. Hamidiye Tabyasının gücüne değinen deniz uzmanları Boğazın ancak Hamidiye ve Kilitbahir yok edildikten sonra zorlanabileceğini belirtmiştir. ${ }^{45}$

Amerikan basını Fransız savaş gemisi Bouvet ile bir İngiliz savaş gemisinin battığını, başka bir İngiliz zırhlısının sahilde sürüklenerek parçalara ayrıldığını ve diğer üç müttefik gemisinin ise büyük hasar alarak kullanılamaz hale geldiğini yazmıştır. Çanakkale Boğazı'ndaki Ayrıca Türk kalelerinin susturulamadığını ve garnizonların uğradıkları kayıpların fazla olmadığını, yaklaşık yedi saat süren çatışmalarda Türklerin büyük bir topçu başarısı elde ettiklerini yazmıştır. ${ }^{46}$ The Guthrie Daily Leader gazetesi ise Müttefiklere ait üç savaş gemisinin battığı yerleri harita üzerinde okuyucularına duyurmuştur. ${ }^{47}$ Türklerin başarı hikâyesi Amerikan basınında yer almış ve basında Cevat Paşa komutasındaki Türk ordusunun Müttefik saldırıları karşında çok büyük bir zafer kazandığı belirtilerek bu başarının Türklerin moralini oldukça yükselttiği söylenmiştir. ${ }^{48}$ Çanakkale ve Gelibolu savunmasında görev alan Liman von Sanders, von Usedom, Mertens Cevat Paşa ve Esat Paşa ve Enver Paşa ile mülakat yapan Amerikalı gazeteci George Schreiner ise 18 Mart'ta yaşanan çarpışmaların şiddetini anılarında "Hala hayattayım ve o kadar mutluyum ki ayaklarım yere basmıyor" diye yazmışırı. ${ }^{49}$

\subsection{Kara Savașları}

Müttefiklerin Gelibolu'ya çıkarma yapmasıyla Çanakkale Savaşlarının ikinci safhası olan kara savaşları başlamıştır. ${ }^{50} 18$ Mart 1915 'te büyük bir bozgun yaşamış olan Müttefikler, karadan destek almaksızın yalnız deniz kuvvetleriyle Boğazın geçilemeyeceğini anlamışlar ve General Hamilton'un emrinde bir çıkarma ordusu hazırlamışlardır. ${ }^{51}$ Kara harekâtının hedefi, Kilitbahir platosunu zapt ederek Boğazdaki tabyalara hâkim olmak suretiyle donanmanın Çanakkale Boğazı'nı zorlamasına yardımcı olmaktı. ${ }^{52}$ Nisan 1915'in ilk günlerinde Müttefiklerin 30.000'den fazla askeri Çanakkale Boğazı girişinin yakınındaki Limni Adası'na konuşlandırdıkları ve yaptıkları hazırlıklar Amerikan basınında yer almıştır. ${ }^{53}$ Müttefikler Türklerin Çanakkale savunmasında yeterli askeri toplamalarına firsat vermeden kara birliklerinin güvenle indirilecekleri noktalara kadar ilerlemek istemişlerdir. ${ }^{54}$ Türkler ise Çanakkale bölgesindeki birliklerini yeni kuvvetlerle takviye etmiş ve 5. Ordu'yu kurarak başına Mareşal

${ }^{45}$ The Ekalaka Eagle, 27 Ağustos 1915, s.6.

${ }^{46}$ The Fargo Forum and Daily Republican, 24 Mart 1915, s.1; Richmond Times-Dispatch, 25 Mart 1915, s.1; The New York Times, 20 Mart 1915, s.1.

${ }^{47}$ The Guthrie Daily Leader, 1 Nisan 1915, s.4.

${ }^{48}$ N. Hakkı Uluğ, Çanakkale Destanının 50. Yıll, (Turizm ve Tanıtma Bakanlığı Yayınları), s.31; The New York Times, 20 Mart 1915, s.1.d

${ }^{49}$ George Abel Schreiner, From Berlin to Bagdad, Harpers\&Brothers Publishers, New York, 1918, s.126; Mustafa Göleç, a.g.m., ss. 593-635.

${ }^{50}$ Sezen Kılıç, "Liman von Sanders'in Çanakkale Savaşları İle İlgili Bazı İddiaları", Journal of Gazi Academic View, C. VII, S. 14, 2014, s. 10.

${ }^{51}$ Zekeriya Kurşun, a.g.m., s.206

52 Büyük Harbin Tarihi Çanakkale Gelibolu Askeri Harekâtı, (çev. Yzb. Avni), (İstanbul: İstanbul Askeri Matbaası, 1939), s.7. Akt: Recep Çelik, "Çanakkale Savaşları Sırasında Halkın Durumu", Çanakkale Araştırmaları Türk Yıllı̆̆g, Yıl: 13, Bahar 2015, Sayı: 18, s. 413.

${ }^{53}$ Türk kaynaklarında bu rakam yaklaşık 75.000 kişilik olarak belirtilmiştir. (Zekeriya Kurşun, a.g.m., s.206)

${ }^{54}$ Mahir Küçükvatan, “Avustralya Ve Yeni Zelanda Basınında Çanakkale Deniz Savaşı”, Tarih ve Günce, I/1, (2017 Yaz), s.137. 
Liman von Sanders'i getirmiştir. ${ }^{55}$ Onun emrinde ise 3. Kolordu Komutanı Esat Paşa ve 15. Kolordu Komutanı yine bir Alman General olan Weber Paşa bulunmaktayd1. ${ }^{56}$

Çanakkale'deki kara savaşlarında 25-27 Nisan 1915 tarihleri arasında Kumkale Muharebesi, 25 Nisan-13 Temmuz 1915 tarihleri arasında Seddülbahir Muharebesi, 25 Nisan-5 Mayıs 1915 tarihleri arasında Arıburnu Muharebesi, tarihleri arasında 6-10 Ağustos 1915 Kanlısırt ve Conkbayırı Muharebeleri ile 6-27 Ağustos 1915 tarihleri arasında Anafartalar Muharebeleri yaşanmıştır. ${ }^{57}$ Müttefiklerin çıkarma harekâtı 25 Nisan 1915 günü sabaha karşı başlamıştır. The Ocala Evening Star gazetesinde yer alan bir haberde Çanakkale'de yaşanan savaşın şiddetini görmek mümkündür. Gazete savaşın şafak vakti başladığını ve on iki saat sürdüğünü, her iki tarafin da ağır kayıplar verdiğini yazmıştır. Gazete Müttefiklerden gelen haberlere göre Müttefik filosunun kaleleri bombaladığı ve Gelibolu Yarımadası'nda bütün bir Türk taburunu ele geçirdiğini yazmıştır. Müttefiklerin Çanakkale Boğazı'nı zorlamak için ikinci büyük girişimin kara ve deniz yoluyla tüm hızıyla devam ettiğini yazan gazete Türk kaynaklarından gelen haberlere de yer vermiştir. İstanbul'dan gelen haberlerde Müttefiklerin Çanakkale Boğazı'na yaptığı kara saldırısının başarısız olduğu, Mareşal Liman von Sanders yönetimindeki Türk ordusunun, 80.000 Müttefik askerinin tamamını Gelibolu Yarımadası'ndan sürdügünü, düşmanın bir kısmının teknelerine doğru kaçtığı ve kaybolduğu, diğerlerinin ise toplu olarak teslim olduklarını okuyucularına aktarmıştır. ${ }^{58}$

Çanakkale'deki durumun değişmediğini belirten Bryan Daily Eagle and Pilot gazetesi Rus filosunun Karadeniz' in Ereğli limanına saldırdığını ve saldırıda dört evin hasar gördüğünü yazmıştır. ${ }^{59}$ The Wheeling Intelligencer gazetesinde Fransız kuvvetlerinin Kumkale'yi işgal ettiği haberi yer alırken ${ }^{60}$ The Richmond Palladium and Sun-Telegram gazetesi bütün gün süren şiddetli çatışmalardan sonra Suvla Körfezi yakınlarındaki Gelibolu Yarımadası'nda bir Türk taburunun ele geçirildiğini ve İngiliz ve Fransız birliklerinin, Gelibolu Yarımadası'nda Eski Hisarlık'a yakın bir noktada sağlam bir yer edindiklerini yazmıştır. ${ }^{61}$ The Topeka State Journal gazetesi ise İngiliz kuvvetlerinin Gelibolu Yarımadası'nda ilerlediğini ve buranın anakara ile olan bağlantısını yavaş yavaş kestiğini ileri sürmüştür. Gazete bu durumda Türklerin Boğazların Avrupa ve Asya yakaları arasında ileri geri geçişlerinin artık mümkün olamayacağını yazmıştır. ${ }^{62}$

Savaş devam ederken tarafların birbirleriyle çelişen açıklamaları olmuştur. ${ }^{63}$ İngilizlerin amacı Gelibolu şehrini alarak kuzey hattını tutmak, böylelikle Türk ordusuna İstanbul'dan gelen yardımları kesmekti. ${ }^{64}$ İstanbul'dan yapılan açıklamalarda ise Türklerin Çanakkale Boğazı'nda Müttefiklere karşı kesin bir zafer kazandığı bildirilmiştir. İngiliz ve Fransız ifadeleriyle doğrudan çelişen açıklamada, yarımadanın ucundaki Kabatepe'deki kuvvetler hariç, Boğazların Asya ve Avrupa yakasına inen tüm birliklerin sürüldüğü ve Müttefik savaş gemileri ile nakliyelerinin birçoğunun hasar gördüğü bildirilmiştir. ${ }^{65}$ The Sunday Gate City gazetesi de Müttefiklerin ilerleyişine değinerek İngiliz birliklerinin Çanakkale Boğazı'nı batıdan koruyan Türk topraklarını kuşattığını, Asya yakasında ise

\footnotetext{
${ }^{55}$ Zekeriya Kurşun, a.g.m., s.206

56 Mahir Aydın, “Çanakkale Savaşı'nda Kara Muharebeleri”, Güney-Doğu Avrupa Araştırmaları Dergisi, Yıl: 2016-1 S. 29, s.52.

${ }^{57}$ Mahir Aydın, a.g.m., s.54-57.

${ }^{58}$ The Ocala Evening Star, 29 Nisan 1915, s.1.

${ }^{59}$ Bryan Daily Eagle and Pilot, 5 Nisan 1915, s.1.

60 The Wheeling Intelligencer, 28 Nisan 1915, s.1.

${ }^{61}$ The Richmond Palladium and Sun-Telegram, 29 Nisan 1915, s.1.

${ }^{62}$ The Topeka State Journal, 1 May1s 1915, s.1.

${ }^{63}$ The Bridgeport Evening Farmer, 30 Nisan 1915, s.1.

${ }^{64}$ New-York Tribune, 1 May1s 1915, s.1.

${ }^{65}$ The Topeka State Journal, 1 May1s 1915, s.1.
} 
Fransız sömürge birliklerinin de aynı şeyi yaptı̆̆ını yazmıştır. Aynı gazete İngiliz Savaş Dairesi tarafından reddedilmesine rağmen İstanbul tarafından yapılan Türklerin Çanakkale Boğazı boyunca Müttefiklere karşı zafer kazandıkları açıklamasına yer vermiştir. ${ }^{66}$ Nitekim Türkler sadece savunmada kalmamış Anafartalar bölgesine çıkan İngilizlere karşı 27 Nisan 1915 sabahı Arıburnu bölgesinde ilk Türk taarruzunu gerçekleştirmiştir. Bunu 1-2 Mayıs gecesi ve 3-4 Mayıs gecesi Seddülbahir bölgesinde gerçekleştiren taarruzlar takip etmiştir. İngiliz ve Fransız hatlarında çözülmeler başladıysa da Müttefik savaş gemilerinin açtığı şiddetli ateş yüzünden taarruz durdurulmuştur. İtilaf kuvvetlerince $6,7,8$ ve 9 Mayıs günleri karşı saldırılar gerçekleştirilmişse de bu saldırılarda başarısız olmuştur. ${ }^{67}$

The Watchman and Southron gazetesi Mayıs 1915' in başlarında okuyucularıyla paylaştığı haberde Müttefik filosunun büyük kısmının Çanakkale Boğazı'na girdiğini ve kaleleri şiddetli bir şekilde bombaladığını bildirmiştir. Ayrıca Boğazların her iki yakasında şiddetli çatışmaların sürdüğünü, Türklerin takviyelerini hızlandırdıklarını ve Müttefiklerin ilerlemesini önlemeye çalıştıklarını ve her ne kadar kayıplar yaşansa da, Müttefiklerin Çanakkale Boğazı'ndaki kara kuvvetlerinin, Türkleri geri çekilmeye zorladığını ve istikrarlı bir şekilde ilerlediklerini yazmıştır. ${ }^{68}$ Mayıs $1915^{\prime}$ te Müttefik filoları Çanakkale Boğazı boyunca uzanan Türk kalelerine saldırmaya devam etmiş, uçaklar savaş gemilerinin ateşini yönlendirmek için kullanılmış ve her iki tarafta ağır kayıplar vermiştir. ${ }^{69}$ Fransız birlikleri ise Çanakkale Boğazı'nın daha çok Asya yakasında Türklere saldırmıştır. ${ }^{70}$

Müttefiklerin amacı Gelibolu Yarımadası boyunca ilerlemekti. ${ }^{71}$ Çatışmalarda İngiliz zırhlısı Kraliçe Elizabeth Saros Körfezi'nden Müttefiklere yardım ederken, eski Alman kruvazörü Goben yani Sultan Selim Marmara Denizi'nden Türklere yardım etmiştir. ${ }^{72} 18$ Mayıs 1915 gecesi ise Türkler Avustralyalılara saldırmış iki bin kişiyi öldürmüş ve beş bin kişi de yaralamıştır. ${ }^{73}$ Enver Paşa'nın emri doğrultusunda Mareşal Liman von Sanders 19 Mayıs 1915'te Müttefiklere saldırmıştır. Başlangıçta Türkler bazı başarılar kazansa da Anzakların şiddetli savunması sonucu kesin bir sonuç alınamamış ve savaş siper savaşlarına dönüşmüştür. ${ }^{74} 27$ Mayıs 1915 tarihinde ise Türkler İngilizlerin Majestic gemisi batırmıştır. ${ }^{75}$

Haziran 1915'in başında Türklerin Çanakkale'deki kayıplarının kırk bin olduğu Amerikan basınında yer almıştır. ${ }^{76}$. The Daily Gate City gazetesi 2 Haziran 1915'te Atina'dan aktardığ 1 bir habere göre Türklerin son kırk sekiz saat içinde Gelibolu Yarımadası'nda gece saldırılarında korkunç kayıplar verdiği, savaşın başından beri kayıplarının yüz bine yaklaştığı yazmıştır. ${ }^{77}$ Haziran 1915 'in başlarında Müttefikler Gelibolu Yarımadası'nda genel ilerleme sağlasa da Türk topçularının faaliyeti ve şiddetli karşı saldırıları nedeniyle bu kazanımları tam olarak tutamamıştır. ${ }^{78}$ İstanbul'dan yapılan resmi bir açıklamada ise Fransız ve İngilizlerin ağır kayıplar verdiği bildirilmiştir. ${ }^{79}$ The Topeka State Journal

${ }^{66}$ The Sunday Gate City, 2 May1s 1915, s.1.

${ }^{67}$ Zekeriya Kurşun, a.g.m., s.207.

${ }^{68}$ The Watchman and Southron, 5 May1s 1915, s.1.

${ }^{69}$ The Chickasha Daily Express, 6 Mayıs 1915, s.1.

${ }^{70}$ The Ogden Standard, 7 May1s 1915, s.8.

${ }^{71}$ New Britain Herald, 18 May1s 1915, s.9.

72 Bryan Daily Eagle and Pilot, 21 May1s 1915, s.1.

${ }^{73}$ The Daily Ardmoreite, 23 May1s 1915, s.1; Ottumwa Tri-Weekly Courier, 25 May1s 1915, s.1.

${ }^{74}$ Zekeriya Kurşun, a.g.m., s.207.

${ }^{75}$ Grand Forks Daily Herald, 31 May1s 1915, s.1.

${ }^{76}$ New-York Tribune, 2 Haziran 1915, s.3.

77 The Daily Gate City, 2 Haziran 1915, s.1.

${ }^{78}$ The Madison Journal, 5 Haziran 1915, s.2.

${ }^{79}$ The Lakeland Evening Telegram, 17 Haziran 1915, s.1. 
gazetesi İngilizlerin Arıburnu ve Kabatepe'deki durumlarının iyi olmadığını yazmıştır. ${ }^{80}$ Türk raporlarına göre ise Gelibolu Yarımadası'ndaki İngiliz kuvvetlerinin Arıburnu yakınlarından bulundukları yeri terk etmek zorunda kaldıkları bildirilmiştir. ${ }^{81}$ İngiltere'den yapılan açıklamada 31 Mayıs 1915'e kadar Çanakkale Boğazı'ndaki İngiliz kayıpları 38.636 kişi olduğu açıklanmıştır. Ancak Gelibolu Yarımadası'ndaki savaşın Haziran ayında şiddetlenmesi sebebiyle İngilizlerin o güne kadarki kayıplarının büyük oranda arttığına inanıldığı Amerikan basınında yer almıştır. ${ }^{82}$

İngiliz Savaş Dairesinden yapılan açıklamada Türk askerlerinin Gelibolu Yarımadası'nda Müttefik mevzilere yeni bir saldırı düzenlediklerini ancak ağır kayıplarla geri çekilmek zorunda kaldıklarını ileri sürülmüştür. ${ }^{83}$ Türk Savaş Dairesi ise Temmuz 1915'te yaptığı bir açıklamada Gelibolu Yarımadası'nın Müttefiklerin Kabatepe'ye saldırdığını ancak Müttefik savaş gemisinin vurulduğunu ve geri çekilmeye zorlandığını açıklamıştır. ${ }^{84} 2$ Ağustos 1915'in ilk günlerinde The Pensacola Journal gazetesinde Çanakkale'nin Müttefikler için zor bir problem haline geldiğine dair bir yazı kaleme alınmıştır. Çıkarma sırasında Müttefik gemilerinin yarımadaya yönelik topçu ateşi olmasaydı tek bir İngiliz veya Fransız askerinin karaya ayak basamayacağını belirten gazete günler boyunca Müttefik gemilerinin yarımadanın güney ucundaki her noktayı bombaladığını yazmıştır. Böylece Osmanlı birlikleri neredeyse kıpırdayamaz hale getirilmiştir. Ancak gün geçtikçe Türkler daha fazla siper kazmışlar ve Müttefiklere karşı güçlü bir savunma hattı oluşturmuşlardır. ${ }^{85} \mathrm{Bu}$ arada Amerikan basınında Çanakkale Boğazı ve İstanbul'un çöküşünden Rusya'nın muhtemelen diğer ülkelerden daha fazla fayda sağlayacağı, ancak Rus birliklerinin ise Müttefiklere yardım etmek için Gelibolu Yarımadası'na gönderilmesinin pek muhtemel olmadığı yer almıştır. ${ }^{86}$

Ağustos 1915'in başında Liman Von Sanders Associated Press muhabiri ile yaptığı görüşmede askeri durumun kendileri için iyi olduğunu ve İngilizleri Arıburnu'ndan çıkarmayı planladıklarını ancak bunun için acele etmediklerini söylemiştir. ${ }^{87}$ Associated Press muhabiri ile yaptığı görüşmede Enver Paşa ise yeni takviyelerin geldiğini belirterek Gelibolu Yarımadası'nda Müttefikleri kontrol altında tutabileceklerinden emin olduklarını söylemiştir. ${ }^{88}$ Ağustos 1915 'in başlarında Gelibolu Yarımadası'na takviye İngiliz kuvvetleri karaya çıkmış ve çatışmalar şiddetlenmiştir. ${ }^{89}$ Aynı ayın ortalarında Müttefik kuvvetler, Çanakkale Boğazı'ndaki saldırılarını artırmış ve Gelibolu Yarımadası'nda ilerleme kaydetmiştir..$^{90}$ İngiliz-Fransız kuvvetleri Gelibolu Yarımadası'ndaki Arıburnu'nun kuzeyinde ki Türk askerlerine yönelik bir saldırı gerçekleştirmiş ancak bu saldırı güçlü bir karşı saldırı ile geri püskürtülmüsşür. ${ }^{91}$ I. ve II. Anafartalar Zaferi'nden sonra Müttefiklerin yaptığı bütün taarruzlar neticesiz kalmıştır.

Amerikan gazetelerinde Ağustos sonu itibarıyla savaşın Müttefikler tarafından kaybedildiğiyle ilgili haberler yayınlamaya başlanmıştır. Buna rağmen Ağustos ayının sonlarında da taraflar arasındaki çatışmalar şiddetle devam etmiştir. The Daily Gate City gazetesine göre Gelibolu'ya gönderilen, Türk birliklerinin iki bölümü, Müttefiklerin son ağır saldırıları sırasında açı pozisyonda kalmış ve ağır

${ }^{80}$ The Topeka State Journal, 17 Haziran 1915, s.1.

${ }^{81}$ The Evening World, 18 Haziran 1915, s.2.

${ }^{82}$ The Richmond Palladium and Sun-Telegram, 1 Temmuz 1915, s.1.

${ }^{83}$ The Cordova Daily Times, 26 Temmuz 1915, s.1.

${ }^{84}$ The Fargo Forum and Daily Republican, 12 Temmuz 1915, s.1.

${ }^{85}$ The Pensacola Journal, 2 Ağustos 1915, s.1.

${ }^{86}$ The Daily Telegram, 12 Temmuz 1915, s.9.

${ }^{87}$ The Fargo Forum and Daily Republican, 3 Ağustos 1915, s.1.

${ }^{88}$ The Ogden Standard, 11 Ağustos 1915, s.1.

89 Perth Amboy Evening News, 12 Ağustos 1915, s.1.

${ }^{90}$ Evening Times-Republican, 15 Ağustos 1915, s.1.

${ }^{91}$ Ricmond Times Dispatch, 16 Ağustos 1915, s.1. 
kayıplar vermiştir. ${ }^{92}$ The Topeka State Journal gazetesi ise İngiliz güçleri tarafından Gelibolu Yarımadası'nın anakaradan kademeli olarak bağlantısının kesildiğini ve Türklerin Boğazların Avrupa ile Asya kıyıları arasında ileri geri geçişlerinin artık mümkün olmadığını yazmıştır. İstanbul'dan gelen resmi raporlara göre ise Türklerin Müttefiklerin kara ve deniz kuvvetlerine yönelik saldırılarında tutarlı bir ilerleme kaydettiklerini açıklanmıştır. ${ }^{93}$

Ağustos 1915'in sonlarında The Washington Times gazetesinde Müttefiklerin Çanakkale Savaşı'ndaki performanslarını değerlendiren bir yazı kaleme alınmıştır. Yazıda genel olarak hükümet, diplomatik ve askeri çevrelerin Müttefiklerin Çanakkale Boğazı'na karşı saldırıların başarısı konusunda aşırı derecede kötümser hale geldikleri yazılmıştır. Müttefiklerin Türklerin gücünü hafife aldıkları değerlendirilmesinde bulunulan yazıda Müttefiklerin Balkan Savaşları sırasında Türklerin gösterdiği zayıflı̆̆ı dikkate aldıklarını ancak Jön Türk Hükümetin tam kontrolünü sağlamasından bu yana Türkiye'de gerçekleşen yenilenme ve yeniden yapılanmayı tamamen göz ardı ettiklerini aktarmıştır. Ayrıca Boğazların Müttefik filosu tarafindan zorlanmasının zor olduğu çünkü Türklerin savunma hazırlıkları için yeterli zamana sahip oldukları değerlendirilmesinde bulunulmuştur. Benzer bir eleştiride Gelibolu Yarımadası'ndaki kara harekâtına karşı yapılmıştır. Müttefiklerin sadece Türklerin gücünü büyük ölçüde küçümsemekle kalmadıkları, aynı zamanda, saldırmak için geç kaldıkları belirtilmiştir. İstanbul'un kara yoluyla ele geçirilmesinin tamamen imkânsız olduğuna inanılmasa da, saldırının siper savaşlarına indiği ve ancak uzun bir harekâttan sonra Müttefiklerin başarılı olabileceği yorumunda bulunulmuştur..$^{94}$

The Washington Times gazetesi Gelibolu Yarımadası'nda devam eden operasyonlarda birinci ve ikinci kara saldırılarının başarısız olması üzerine Müttefiklerin üçüncü bir plan hazırladıklarını yazmıştır. Müttefiklerin İstanbul'a giden yolu açma konusundaki ilk askeri çabasının İngilizlerin Çanakkale Boğazı'nın Gelibolu ve Fransızların ise Asya kıyıları boyunca saldırması olduğunu yazan gazete bu saldırının başarılı olmadığını Fransızlar denize geri sürüldüğünü, İngilizler ise tüm kıyıyı kontrol edemediğini okuyucularına aktarmıştır. The Washington Times Müttefik kuvvetlerin Gelibolu'nun güney ucunda yoğunlaşarak eş zamanlı yaptıkları ikinci saldırının da Türklerin savunma hatlarını çok güçlü bir şekilde oluşturmalarından dolayı başarısız olduğunu yazmıştır. Ağustos 1915'in sonlarında Müttefiklerin Suvla Körfezi boyunca yeni çıkarmalar yapmayı düşündüklerini ve bu sayede Müttefiklerin daha büyük bir gücü kullanılabilmelerinin avantaj olduğunu yazan gazete Müttefiklerin savaş hattının on iki milini birleştirerek ilk kez Türklere karşı hareket edecek bir konuma ulaştıklarını ve Türk askerlerinin savunmalarıyla orantılı bir kuvvete sahip olduklarını ifade etmiştir. ${ }^{95}$

New Britain Herald gazetesi Müttefiklerin muazzam ve savurgan olan top ve uçak mühimmatı harcamaları sebebiyle Gelibolu'nun harabeye döndüğünü okuyucularına aktarmıştır. ${ }^{96}$ The Hattiesburg News gazetesi ise İngiliz gemilerinin topçu ateşine karşı yarımadadaki bir metrekarelik toprak parçasının güvenli olmadığını ve İngiliz nişancıların sabah saat 5.15'te top atışına başladıklarını yazmıştır. Ayrıca gazete bombalamaların uzun süredir devam etmesi sebebiyle artık Türk bataryalarının çok dikkatini çekmediğini bildirmiştir. Savaş koşulları altında Türklerin kaderciliğinin muhteşem bir şey olduğunu belirten gazete Türklerin ölümü karş1lama biçimlerine dikkati çekmiştir. ${ }^{97}$

${ }^{92}$ The Daily Gate City, 25 Ağustos 1915, s.1.

${ }^{93}$ The Topeka State Journal, 25 Ağustos 1915, s.1.

${ }^{94}$ The Washington Times, 26 Ağustos 1915, s.2.

${ }^{95}$ The Washington Times, 26 Ağustos 1915, s.2.

${ }^{96}$ New Britain Herald, 30 Ağustos 1915, s.5.

${ }^{97}$ The Hattiesburg News, 13 Ağustos 1915, s.4; Konuyla ilgili ayrıca bakınız: Hasan Mert, "Çanakkale'de Ölüm”, Tarih Incelemeleri Dergisi, C. XXVI, S. 1, Temmuz 2011, ss.151-172. 
Büyük kuvvetlerle Türklere saldıran İngilizlerin Ağustos 1915'teki kayıpları 50.000'ni aşmıştır. ${ }^{98}$ Özellikle Suvla Körfezi bölgesinde İngilizler ciddi kayıplar vermiştir. ${ }^{99}$ Cephede görev yapan Associated Press muhabirinden gelen mektubu yayımlayan The Fargo Forum and Daily Republican gazetesi Çanakkale'de durumun İngilizler için iç açıcı olmadığı aktarmıştır. Gelibolu Yarımadası'nın Anafarta-Arıburnu cephesindeki Müttefik birlikleri için durumun umut vadetmediğini bildiren muhabir 26 ve 27 Ağustos 1915’te Türklere yönelik iki saldırı olduğundan bahsetmiştir. Bu saldırılarda Türklerin büyük kayıp vermekler birlikte İngiliz kayıplarının 11 ile 13 bin arasında olduğunu yazmıştır. ${ }^{100}$

Eylül 1915'te Çanakkale'de hem karada hem de denizde çatışmaların yeniden başlayacağı ve Müttefiklerin Seddülbahir ile Suvla Körfezi'ne eşzamanlı saldırılara hazırlandığına dair haberler Amerikan basınına yansımıştır. İstanbul'dan yapılan resmi açıklamada ise bu saldırıların ertelendiği duyurulmuştur. ${ }^{101}$ The Daily Ardmoreite gazetesi Paris'ten yapılan bir açıklamaya yer vererek Gelibolu Yarımadası'ndaki Türk kuvvetlerinin önemli bir bölümünün Müttefikler tarafından kuşatıldı̆̆ını ve teslim olmalarının yakın olduğu aktarmıştır. ${ }^{102}$ Evening Times-Republican gazetesi İstanbul'a yol açmak için Gelibolu Yarımadası'nda savaşan İngiliz ve Fransızların savaşan bir adam olarak Türkler ve aynı zamanda Müslümanların kişisel nitelikleri hakkında yüksek bir fikir edindiklerini yazmıştır. Gazete yarımadadaki Müttefik kuvvetlerin büyük bir İtalyan ordusu tarafından güçlendirildiği de eklemiştir. ${ }^{103}$

Ekim 1915'te General Sir Hamilton'ın Çanakkale Boğazı kuvvetlerinin komutasından alınması, Gelibolu Yarımadası'ndan olası bir geri çekilme söylentilerini gündeme getirmiştir. Bununla birlikte, General Sir Charles Munro'nun komutan olarak atanmasını Amerikan basını saldırıların yeniden başlayabileceği olarak değerlendirmiştir. ${ }^{104}$ General Monro Gelibolu'ya gelinceye kadar Binbaş1 Tümgeneral William Riddel Birdwood, birliklere geçici komutan olarak atanmıştır. Bu atama İstanbul'a giden yolu açmak için Gelibolu Yarımadası'na gönderilen Müttefik kuvvetleri için her şeyin yolunda gitmediğinin bir göstergesi olarak Amerikan gazetelerinde yer almıştır. Nitekim İngiliz parlamentosunda Viscount Milner, birliklerin Gelibolu'dan çekilmesini ve savaşın başka bir bölgesine transfer edilmesini önermiştir. ${ }^{105}$ Lord Lansdowne ise Çanakkale'deki savaşa devam edilip veya çekileceği noktasında hükümet üyelerinin bir şey diyemeyeceğini söylemiştir. ${ }^{106}$

Ekim 1915'in ortalarında Alman ve Avusturyalıların Sırbistan'a yönelik faaliyetlerin Müttefiklerin Çanakkale'den çekilmesini gündeme getirmiştir. Avustralya'nın İngiltere'nin yardımına gönderdiği askerlerin çoğunun Çanakkale'de savaştığını belirten The Alaska Citizen gazetesi bu durumda binlerce Avustralyalıların boşuna ölmüş olacağını aktarmıştır. The Alaska Citizen London Times gazetesinden aktardığı haberinde Gelibolu Yarımadası'nda veya Çanakkale Boğazı boyunca Müttefiklerin Türk kalelerini almalarının neredeyse imkânsız olduğunu yorumunda bulunmuştur. ${ }^{107}$ Türk Savaş Dairesi Ekim 1915'in sonlarında Müttefiklere karşı Arıburnu ve Seddülbahir'de önemli başarılar kazandığını açıklamıştır. ${ }^{108}$ Kasım 1915'in başlarında İngiliz-Fransız filosunun iki kruvazörü, Seddülbahir'de Türk mevkilerini bombalamış ancak Türkler önemli başarılar kaydetmiştir. ${ }^{109}$ Müttefiklerin Türklere yönelik

${ }^{98}$ The Guthrie Daily Leader, 31 Ağustos 1915, s.1.

${ }^{99}$ The Washington Times, 5 Eylül 1915, s.2.

${ }^{100}$ The Fargo Forum and Daily Republican, 19 Ekim 1915, s.1.

${ }^{101}$ The Daily Gate City, 14 Eylül 1915, s.2.

${ }^{102}$ The Daily Ardmoreite, 3 Eylül 1915, s.1.

${ }^{103}$ Evening Times-Republican, 1 Ekim 1915, s.7.

${ }^{104}$ The Fargo Forum and Daily Republican, 19 Ekim 1915, s.1.

${ }^{105}$ New Britain Herald, 19 Ekim 1915, s.9.

${ }^{106}$ The Ogden Standard, 19 Ekim 1915, s.10.

${ }^{107}$ The Alaska Citizen, 18 Ekim 1915, s.1.

${ }^{108}$ The Ogden Standard, 30 Ekim 1915, s.1.

${ }^{109}$ The Richmond Palladium and Sun-Telegram, 2 Kasım 1915, s.8. 
saldırıları sonraki günlerde de devam etmiştir. ${ }^{110}$ Ancak Kasım 1915'te cepheye gelen İngiliz Harbiye Nazırı Lord Kitchener durumu görünce bölgeyi tahliye etmekten başka çare kalmadığına karar vermiştir. $^{111}$

Aralık ayında Müttefiklerin Gelibolu Yarımadası'nın kuzeyindeki konumlardan vazgeçerek, sadece güney ucunda tutulan toprak şeridini korumaya çalıştıkları Amerikan basınına yansımıştır. ${ }^{112}$ Ayrıca İngiliz birliklerinin Suvla Koyu'ndan çekilmesi ve Gelibolu Yarımadası'ndaki Anzak askerlerinin başka bir operasyon alanına aktarıldığının açıklanması Müttefiklerin Gelibolu'yu terk edebileceği yorumlarına sebep olmuştur. ${ }^{113}$ Gelibolu Yarımadası'nın Suvla ve Anzak bölgelerindeki İngiliz birlikleri geri çekilmiştir. Tüm birlikler, silahları ve depolarıyla birlikte, önemsiz kayıplarla başka bir operasyon alanına başarıyla transfer edildiği Müttefikler tarafından açıklanmış ancak çekilen askerin hangi cepheye gönderildiğinden bahsedilmemiştir. Çanakkale Savaşlarının en sert karşılaşmalarından ve en ağır kayıplarından bazıları, İngilizlerin terk ettiği bu mevkilerde meydana gelmiştir. ${ }^{114}$

Berlin'den yapılan bir açıklamada ise Türk Kuvvetlerinin 18-19 ve 19-20 Aralık 1915'te düşmana karşı bir saldırı başlattığı ve Müttefiklerin ağır kayıplar verdiği bildirilmiştir. ${ }^{115}$ Türk topçularının Gelibolu Yarımadası'ndaki Müttefik batarya ve siperlere karşı başarılı saldırıları sonraki günlerde de devam etmiştir. ${ }^{116}$ Müttefikler 19-20 Aralık 1915 gecesi Anafartalar ve Arıburnu cephesinden, 8-9 Ocak 1916'da da Seddülbahir'den çekilmişlerdir. Müttefiklerin savaşı kaybetmelerinde kendi kuvvetlerini Türk kuvvetlerinden oldukça güçlü olduğuna inanmaları, bu sebeple gerekli hazırlık ve planları tam olarak yapmamaları, yaptıkları hatalar karşısında gerekli hızlı tepkiyi vererek çözüm üretmemekte gecikmeleri, Türk birliklerinin hızlı hareketi ve savaş kabiliyetleri, Türk ve Müttefiklerin ölüme farklı bakış açıları etkili olmuştur. Nisan 1915'teki çıkarmasıyla Ocak 1916'daki çekilme arasında geçen 259 günde Müttefikler Gelibolu'ya yarım milyon asker göndermiştir. Denizaltı, uçak ve modern topların kullanıldığı bu savaşta Müttefik askerlerden yarıdan fazlası hayatını kaybetmiştir. ${ }^{117}$

Müttefiklerin Çanakkale Cephesi'nde başarısız olmaları savaşın gidişatını önemli ölçüde değiştirmiş ve gibi tüm dünyayı etkileyen sonuçları olmuştur. Çanakkale'nin tahliye haberi Türkleri sevince boğmuş ve bu önemli zafer haberi tüm il ve ilçelerde coşkuyla kutlanmıştır. Türk basını, Müttefiklerin Anafartalar ve Arıburnu'ndan çekilmesini büyük zafer olarak duyurmuş ve Türk milletinin asırlardan beri şevkle beklediği büyük bir zafer kazandığını açıklamıştır. ${ }^{118}$

\section{Sonuç}

Dünyanın en güçlü ordularının topyekûn saldırılarına rağmen Çanakkale Savaşları, Osmanlı Devleti'nin açık zaferiyle sonuçlanmıştır. ${ }^{119}$ Çanakkale Cephesi Birinci Dünya Savaşı'nın kilit cephelerinden biri olması sebebiyle dünya kamuoyunun da yakından izlediği bir yer olmuştur. $\mathrm{Bu}$ yüzden birçok gazeteci gibi Amerikalı gazeteciler ile Amerikan basını da bu bölgeye ilgi duymuş ve burada yaşanan gelişmeleri dikkatle takip etmiştir. Amerikan basını savaşan her iki tarafinda haberlerini yayımlamıştır. Haber kaynağı olarak iki tarafında haber kaynaklarını kullanmıştır. ABD ilk başlarda

${ }^{110}$ The Watchman and Southron, 24 Kasim 1915, s.1.

111 Zekeriya Kurşun, a.g.m., s.207.

112 The Pensacola Journal, 3 Aralık 1915, s.2.

113 Tonopah Daily Bonanza, 20 Aralık 1915, s.1.

114 The Citizen-Republican, 23 Aralik 1915, s.7.

115 The Fargo Forum and Daily Republican, 22 Aralık 1915, s.1.

116 The Sunday Telegram, 26 Aralık 1915, s.1.

117 Alan Moorehead, Gelibolu, (çev. Ali Cevat Akkoyunlu), (İstanbul: Doğan Kitap, 2000), s. 326-330.

118 Mücahit Özçelik, “İtilaf Devletlerinin Çanakkale’yi Tahliyesinin Türk Basınına Yansımaları”, Çanakkale Araştırmaları Türk Yıllı̆̆g, Y11: 13, Bahar 2015, Sayı: 18, ss. 447-464.

119 Sait Aşgın, “Çanakkale Savaşlarının Arka Planı”, Türk İdare Dergisi, S. 470, Mart 2011, s.26 
savaşa katılmayan bir ülke olan Amerikan basını konuya kısmen de olsa tarafsız yaklaşmış ve her iki tarafın gözünden gelişmeleri aktarmıştır. Ancak bu aktarmanın daha çok Müttefik Devletlerin gözünden olduğunu belirtmek gerekir.

Amerikan basınında Çanakkale Boğazı ve İstanbul'un çöküşünden Rusya'nın muhtemelen diğer ülkelerden daha fazla yarar sağlayacağını ancak Rus birliklerinin Müttefiklere yardım etmek için Gelibolu Yarımadası'na gönderilmesinin pek muhtemel olmadığı daha savaşın başında belirtmiştir. Çanakkale'de yaşanan savaşın ne denli şiddetli olduğunu Amerikan basınından takip etmek mümkündür. Tarafların verdiği ağır kayıpları sayfalarına taşıyan Amerikan gazeteleri cephedeki muhabirleri veya diğer haber kaynaklarından elde ettikleri bilgileri okuyucularına aktarmıştır. Amerika basınında çıkan haberlere bakıldığında Müttefiklerin savaşı kazanmak için neredeyse her yola başvurdukları görülmektedir. Nitekim Amerikan gazeteleri Müttefik saldırılarıyla Gelibolu'nun büyük oranda harap olduğu ancak birkaç evin sağlam kaldığı yazılmıştır. Ayrıca tarlalarda hasadın yapılamadığı, köylerde sağlam kalan az sayıda dükkânın boş olduğu, limanlardaki teknelerin kaybolduğu, kasaba, köy ve kırsal kesimde yaşayanların bölgeyi terk ettiğini, bölgede sadece askerlere rastlanıldığını aktarmıştır.

Amerikan basını Müttefiklerin Türkler karşında neden kaybettikleri konusunu da irdelemiştir. Müttefiklerin Türklerin askeri gücünü hafife aldıklarının belirten Amerikan gazeteleri Müttefiklerin Balkan Savaşları sırasında Türklerin gösterdiği zayıflığı dikkate aldıklarını ancak İttihat ve Terakki Cemiyeti'nin tam kontrolünü sağlamasından bu yana Türkiye'de gerçekleşen yenilenme ve yeniden yapılanmayı tamamen göz ardı ettiklerini yazmıştır. Müttefiklerin İstanbul'a ulaşmak için önce deniz yolunu denediklerini ancak bunun başarısız olması üzerine kara çıkarmalarına başladıklarını belirten Amerikan gazetelerinde Müttefiklerin karadan Gelibolu'yu alıp İstanbul'a ulaşmak için üç büyük plan yaptıkları ve bu planların başarısızla sonuçlandığını takip edilebilmektedir. Amerikan gazeteleri İstanbul'a yol açmak için Gelibolu Yarımadası'nda savaşan İngiliz ve Fransızların Türklerin savaşçı özellikleri ve aynı zamanda Müslümanların kişisel nitelikleri hakkında yüksek bir fikir edindiklerini belirtmiştir. Amerikan basını savaş koşulları altında Türklerin kaderciliğinin muhteşem bir şey olduğunu üzerinde durarar Türklerin ölümü karşılama biçimlerine dikkati çekmiştir.

Çanakkale'de yaşanan savaşla ilgili değerlendirmede bulunan Amerikan basını Müttefiklerin Çanakkale'de yaşadıkları deniz gücü kayıplarının XVII. ortalarında İngilizlerin Hollandalılarla yaptığı mücadeleden ve 1905 yılında Japonya deniz savaşında Rusların kayıplarından daha büyük olduğunu belirtmiştir. Sadece bu durum bile 18 Mart'ın tek başına Türkler için çok büyük bir zafer olduğunu göstermektedir. Ancak bu başarının sadece Müttefikler açısından değil Türkler açısından ağır bedeli olmuştur. Nitekim Müttefik filosunun Çanakkale'ye girişinden sonraki üç hafta içinde, tarihte o ana kadar bilinen en ağır bombardıman yaşanmıştır. Her iki taraf çok büyük zayiatlar vermiştir. Bu savaş Türklerin bağımsızlıkları için nasıl büyük bir mücadele verdiklerinin açık bir kanıtı olarak Amerikan basınında geniş yer bulmuştur.

\section{Kaynakça}

\section{Resmi Kaynaklar}

BOA, DH. EUM. VRK, 25/8

BOA, DH. EUM. VRK, 25/9

BOA, HR. SYS, 2098/12

BOA, HR. SYS, 2409/21

BOA, HR. SYS, 2409/53

BOA, HR. SYS, 2412/11 


\section{Süreli Yayınlar}

\section{Bridgeton Pioneer}

Bryan Daily Eagle and Pilot

Evening Star

Fulton County Tribune

Grand Forks Daily Herald

New Britain Herald

New-York Tribune

Ottumwa Tri-Weekly Courier

Perth Amboy Evening News

Richmond Times-Dispatch

The Alaska Citizen

The Appeal

The Bridgeport Evening Farmer

The Caldwell Watchman

The Chickasha Daily Express

The Citizen-Republican

The Cordova Daily Times

The Daily Ardmoreite

The Daily Gate

The Daily Gate City

The Daily Telegram

The Ekalaka Eagle

The Evening World

The Fargo Forum and Daily Republican

The Guthrie Daily Leader

The Hattiesburg News

The Lakeland Evening Telegram

The Madison Journal

The New York Times

The Ocala Evening Star

The Ogden Standard

The Pensacola Journal

The Richmond Palladium and Sun-Telegram

The Seward Gateway

The Sunday Gate City

The Sunday Telegram

The Topeka State Journal

The Washington Times

The Watchman and Southron

The Wheeling Intelligencer

Tonopah Daily Bozanza 


\section{Kitap ve Makaleler}

Albayrak, Muzaffer, Çanakkale Cephesi'nde Yabancı Gazeteciler, 100. Yılında Çanakkale, İstanbul: Zeytinburnu Belediyesi Kültür Yayınları, Mart 2016, ss.195-214.

Apuhan, Recep Şükrü, Çanakkale Geçilmez, Dördüncü Bask1, İstanbul: 2005.

Aşgın, Sait, “Çanakkale Savaşlarının Arka Planı”, Türk İdare Dergisi, S. 470, Mart 2011.

Aydın, Mahir, “Çanakkale Savaşı'nda Kara Muharebeleri”, Güney-Doğu Avrupa Araştırmaları Dergisi, Y11: 2016-1 S. 29, ss. 47-63.

Başak Tolga, "The New York Times" Gazetesinin Çanakkale Boğazı Günlüğü (1-31 Mart 1915)", Atatürk Üniversitesi Edebiyat Fakültesi Sosyal Bilimler Dergisi, C.XI S.46, Haziran 2011, ss.1-42 Beydilli, Kemal, “Boğazlar Meselesi”, DİA, İstanbul, 1992, C. VI, ss.266-269.

Birinci Dünya Harbi’nde Türk Harbi, Ankara: Genel Kurmay Basımevi, 1991.

Büyük Harbin Tarihi Çanakkale Gelibolu Askeri Harekâtı, (çev. Yzb. Avni), İstanbul Askeri Matbaası, İstanbul 1939.

Çelik, Recep, "Çanakkale Savaşları Sırasında Halkın Durumu”, Çanakkale Araştırmaları Türk Yıllı̆̆ı, Y11: 13, Bahar 2015, Sayı: 18, ss. 411-430, 100. Y11.

Eyicil, Ahmet, "Çanakkale Savaşları”, Gaziantep Üniversitesi Sosyal Bilimler Dergisi, 2009 8(1), s.317370.

G. A. Bowen, "Document Analysis As A Qualitative Research Method". Qualitative Research Journal, 2009 9(2), 27-40.

Göleç, Mustafa, "Amerikalı Bir Gazetecinin Gözüyle Çanakkale Deniz ve Kara Savaşları: George Abel Schreiner ve Çanakkale Günlükleri”, Çanakkale Araştırmaları Türk Yıllı̆̆l, Y1l: 13, Bahar 2015, S. 18 , ss. 593-635

K1lıç, Sezen, “Liman von Sanders'in Çanakkale Savaşları İle İlgili Bazı İddiaları", Journal of Gazi Academic View, c. VII, S. 14, 2014, s.1-19.

Kurşun, Zekeriya, “Çanakkale Muharebeleri”, DİA, İstanbul, 1993, C. VIII, s.205-208.

Küçükvatan, Mahir, “Avustralya ve Yeni Zelanda Basınında Çanakkale Deniz Savaşı”, Tarih ve Günce, I/1, (2017 Yaz), ss. 125-152.

Mert, Hasan, “Çanakkale'de Ölüm”, Tarih İncelemeleri Dergisi, C. XXVI, S. 1, Temmuz 2011, 151172

Moorehead, Alan, Gelibolu, (çev. Ali Cevat Akkoyunlu), İstanbul: Doğan Kitap, 2000.

Osmanlı Belgelerinde Çanakkale Muharebeleri, Ankara: Osmanlı Arşivi Daire Başkanlığı, 2005.

Özçelik, Mücahit, "İtilaf Devletlerinin Çanakkale’yi Tahliyesinin Türk Basınına Yansımaları", Çanakkale Araştırmaları Türk Yıllı̆̆ı, Y1l: 13, Bahar 2015, Sayı: 18, ss. 447-464.

Schreiner, George Abel, From Berlin to Bagdad, New York: Harpers\&Brothers Publishers, 1918.

Selçuk, Mustafa, “Çanakkale Savaşları Sırasında Osmanlı Hükümeti’ni ve Padişahı İstanbul'dan Taşıma Planları”, Atatürk Araştırma Merkezi Dergisi, C. XXIV, S.70, s. 195-212.

Uluğ, N. Hakkı, Çanakkale Destanının 50. Yılı, Turizm ve Tanıtma Bakanlığı Yayınları.

Tuncoku, Mete, Çanakkale 1915 Buzdağının Altı, Ankara: Türk Tarih Kurumu Basımevi, 2002.

A. Yıldırım ve H. Şimşek, Sosyal Bilimlerde Nitel Araştırma Yöntemleri, Ankara: Seçkin Yayınları, 2013. 


\section{Ekler}

Ek-1: İstanbul'un Savunmasını ve Gelibolu Bölgesini Gösteren bir Harita ${ }^{120}$

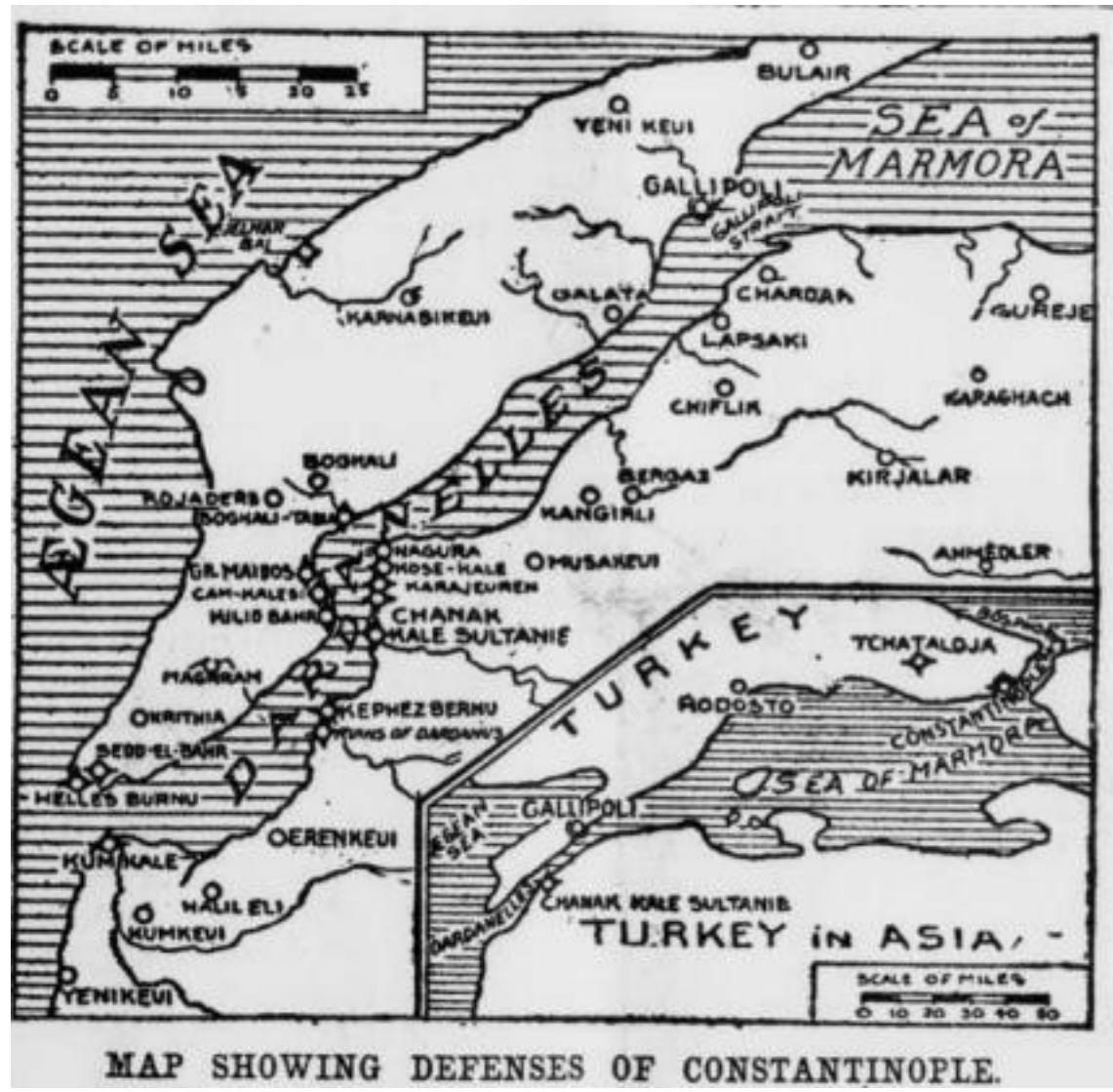

Ek-2: Gelibolu Yarımadası'na Çıkarma Yapan Müttefik Askerleri ve Hamiye Zırhlısında Görevli Mürettebatının Bir Bölümü ile Solda Geminin Alman Komutanı Yüzbaşı Kottwitz. ${ }^{121}$

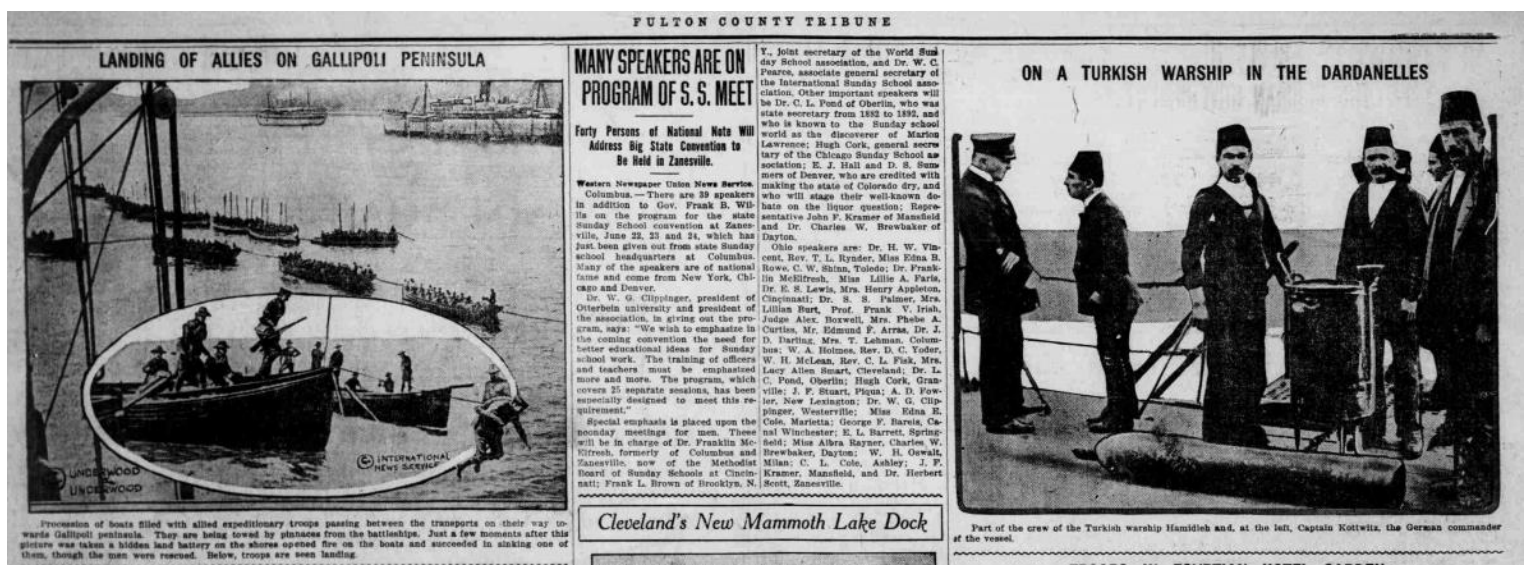

${ }^{120}$ Bridgeton Pioneer, 29 Nisan 1915, s. 3.

${ }^{121}$ Fulton County Tribune, 18 Haziran 1915, s. 3. 
Ek-3: New-York Tribune gazetesinde İngilizlerin Gelibolu'daki İlerlemelerini Anlatan Bir Haber ve İngiliz Ordusunun Türklerle Karşılaştığı Yerleri Gösteren Bir Harita ${ }^{122}$

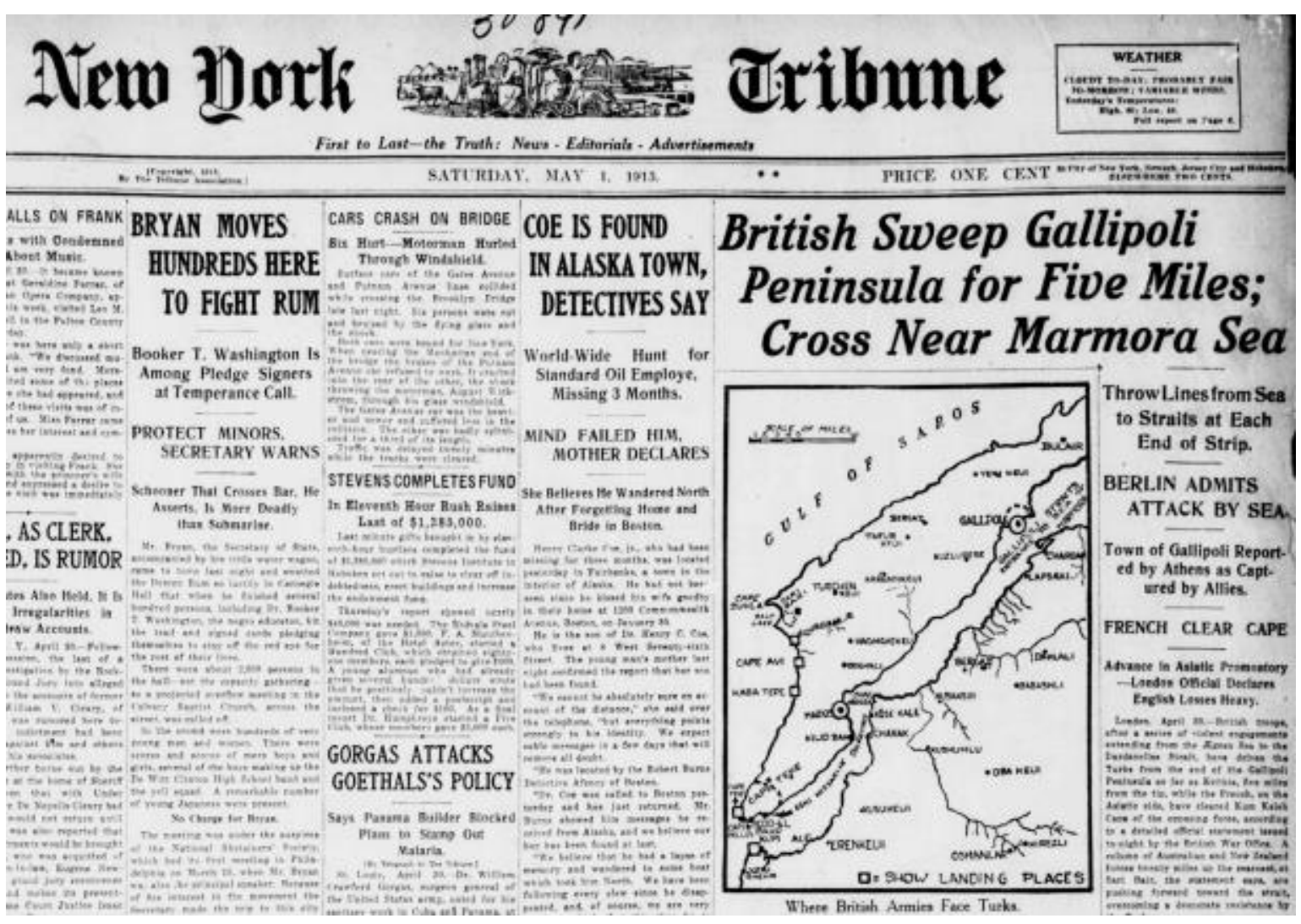

${ }^{122}$ New-York Tribune, 1 May1s 1915, s.1 